\title{
Substrate oxidation, obesity and exercise training
}

Citation for published version (APA):

Blaak, E. E., \& Saris, W. H. M. (2002). Substrate oxidation, obesity and exercise training. Best Practice \& Research Clinical Endocrinology \& Metabolism, 16(4), 667-678. https://doi.org/10.1053/beem.2002.0226

Document status and date:

Published: 01/01/2002

DOI:

10.1053/beem.2002.0226

Document Version:

Publisher's PDF, also known as Version of record

\section{Please check the document version of this publication:}

- A submitted manuscript is the version of the article upon submission and before peer-review. There can be important differences between the submitted version and the official published version of record.

People interested in the research are advised to contact the author for the final version of the publication, or visit the DOI to the publisher's website.

- The final author version and the galley proof are versions of the publication after peer review.

- The final published version features the final layout of the paper including the volume, issue and page numbers.

Link to publication

\footnotetext{
General rights rights.

- You may freely distribute the URL identifying the publication in the public portal. please follow below link for the End User Agreement:

www.umlib.nl/taverne-license

Take down policy

If you believe that this document breaches copyright please contact us at:

repository@maastrichtuniversity.nl

providing details and we will investigate your claim.
}

Copyright and moral rights for the publications made accessible in the public portal are retained by the authors and/or other copyright owners and it is a condition of accessing publications that users recognise and abide by the legal requirements associated with these

- Users may download and print one copy of any publication from the public portal for the purpose of private study or research.

- You may not further distribute the material or use it for any profit-making activity or commercial gain

If the publication is distributed under the terms of Article $25 \mathrm{fa}$ of the Dutch Copyright Act, indicated by the "Taverne" license above, 
6

\title{
Substrate oxidation, obesity and exercise training
}

\author{
Ellen E. Blaak* PhD \\ Associate Professor of Human Biology
}

Wim H. M. Saris* PhD, MD

Professor of Human Biology/Nutrition

Department of Human Bialogy, Nutrition Research Centre, Mastricht University, The Netheriands

Regular physical exercise is of the utmost importance in the treatment of obesity because exercise is one of the factors determining long-term weight maintenance in weight reduction programmes and because exercise has been associated with a reduced risk for developing type 2 diabetes mellitus and cardiovascular disease. Obesity is associated with an impaired utilization of fat as a fuel during post-absorptive conditions, during $\beta$-adrenergic stimulation and possibly during exercise, although the latter data are controversial.

One of the underlying mechanisms for the positive effect of exercise training in obesity may be related to its effects on fat utilization because exercise training has been shown to increase basal fat oxidation and exercise fat oxidation in lean volunteers. Data on the effect of aerobic exercise training on exercise fat oxidation are controversial, whereas the available data indicate that exercise training may not be able to increase resting fat oxidation or 24-hour fat oxidation in obese subjects. Because disturbed muscle fat oxidation may be a primary event in the aetiology of obesity it is of the utmost importance to obtain more information on how and whether exercise training may be able to compensate for these impairments.

Key words: obesity; exercise training; skeletal muscle; fatty acid utilization.

Exercise is a cornerstone in the treatment of obesity because physical exercise is one of the factors determining long-term weight maintenance in weight-reduction programmes. ${ }^{1-4}$ Beside the effects on body weight and body composition, physical exercise is associated with important health benefits: insulin sensitivity may improve ${ }^{5}$, blood lipid profile may improve ${ }^{6}$, blood pressure may reduce $^{7}$ and psychological well-being may improve. ${ }^{8}$ This is illustrated in the finding that the incidence of type 2 diabetes mellitus ${ }^{9}$ and cardiovascular mortality are much lower in obese persons who are fit than in those who are unfit. ${ }^{10}$ For this reason, endurance exercise may be particularly beneficial for persons with abdominal obesity because of their increased risk of type 2 diabetes mellitus and cardiovascular disease.

Based on intensive research in the past decade, it can be concluded that obesity is associated with an impaired utilization of fat as a fuel. Impairments in the ability of

*Address for correspondence: Department of Human Biology, Nutrition Research Centre, Maastricht University, P.O. Box 616,6200 MD Maastricht, The Netherlands.

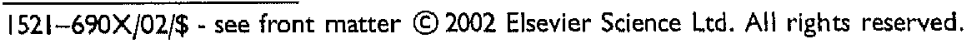


skeletal muscle to utilize plasma free fatty acids (FFA) have been reported during post-absorptive conditions" and $\beta$-adrenergic stimulation (ref. 12; see Figure I). Additionally, persistent impairments in FFA utilization have been reported after weight loss in obese subjects, suggesting that these defects could be primary to the obese state. This is consistent with findings that a decreased reliance for lipid oxidation is a risk factor for weight gain ${ }^{13}$ and for weight regain ${ }^{14}$ after weight loss. Thus, this blunted capacity to oxidize fatty acids may play an important role in the development of a positive fat balance and increased fat storage in obesity.

One of the underlying mechanisms for the positive effects of exercise training in obesity may be related to its effects on fat utilization. Exercise has been shown to stimulate fat oxidation during both post-absorptive conditions ${ }^{15}$ and exercise or

Obesity and skeletal muscle metabolism

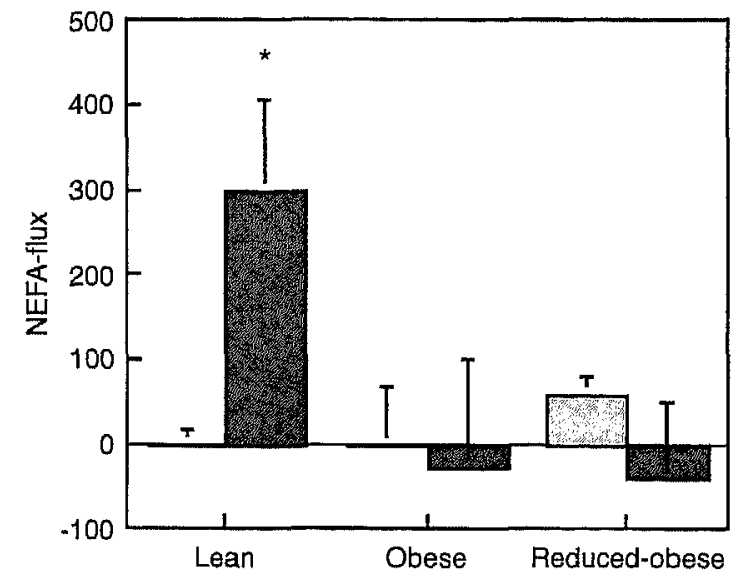

Baseline

Isoprenaline

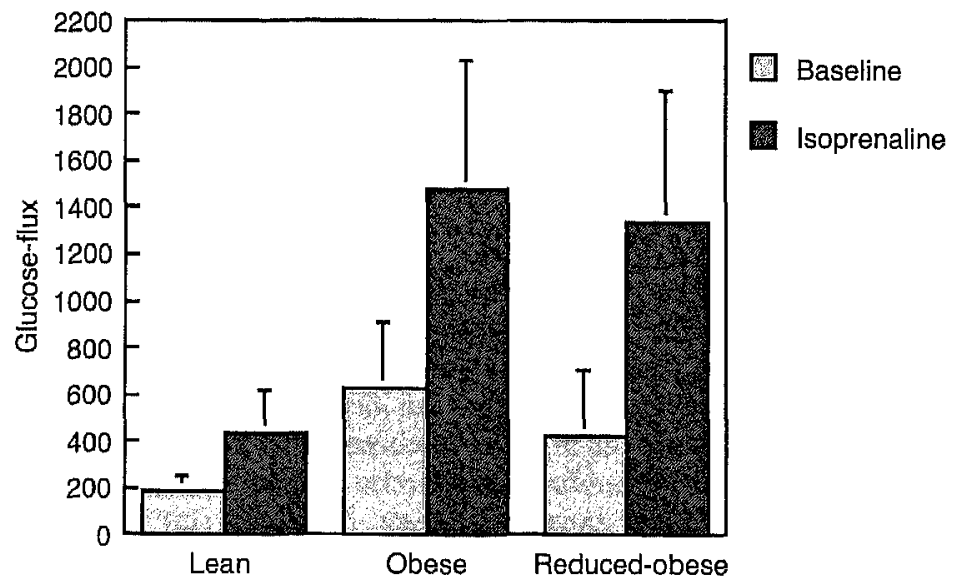

in $\mathrm{nmol} / 100 \mathrm{ml}$ forearm. $\mathrm{min}$

Figure I. Skeletal muscle fatty acid uptake (NEFA-flux, upper panel) and glucose uptake (flux, lower panel) in lean and obese and reduced-obese males $(n=8)$ during post-absorptive conditions and during infusion of the non-selective $\beta$-agonist isoprenaline. Data are adapted from references 12 and 20. 
catecholamine stimulation in lean subjects. ${ }^{16-18}$ If similar effects occur in obese subjects, exercise may be able to compensate for the impaired ability to oxidize fat, thereby promoting a negative fat balance and weight reduction in obese subjects and the maintenance of fat balance and body weight in reduced-obese subjects.

\section{SUBSTRATE UTILIZATION IN OBESITY}

As indicated above, there are numerous indications that obesity is associated with a diminished capacity to oxidize fat. Impairments in the ability to mobilize fatty acids from adipose tissue and to oxidize fatty acids in skeletal muscles have been reported in obese subjects during catecholamine stimulation (through $\beta$-adrenoceptors; (ref. 12, see Figure 1). Also, skeletal muscle fatty acid oxidation has been shown to be impaired in visceral obese subjects during post-absorptive conditions, whereas glucose uptake and glucose oxidation were increased. 11,19 Weight reduction did not improve the impaired capacity to utilize fatty acids in obese subjects (refs 20 and 21 ; Figure 1), suggesting that these defects could be primary to the obese state rather than adaptational responses. This is consistent with the finding that a decreased reliance on lipid oxidation is a risk factor for weight gain in Pima Indians in Arizona. ${ }^{13}$ Additionally, unlike never-obese women, post-obese women showed decrements in post-prandial and 24- hour fat oxidation 22,23, and a high resting respiratory quotient has been correlated with weight gain in postobese women. ${ }^{14}$

Wade et $\mathrm{a}^{24}$ reported a positive relationship between percentage body fat and the respiratory exchange ratio during exercise in obese subjects, indicative of a lowered fat oxidation during exercise in obesity. However, this study has been criticized because most subjects in this study were lean (percentage body fat $<25 \%$ ). Also, in this study subjects were exercising at a fixed work load of 100 watt, which may have disturbed the findings due to a relationship between fitness and fatness. Indeed, two subsequent studies could not confirm the results of the Wade study. ${ }^{25,} 26$ There are more recent indications that there may be differences in the source of fatty acids used during exercise in obese subjects as compared to controls. Abdominally obese women have been shown to have an increased utilization of triglyceride-derived fatty acids during exercise. ${ }^{27}$ This seems consistent with findings in obese type 2 diabetic men who showed an increased triglyceride-derived fatty acid utilization and a diminished plasma-derived fatty acid oxidation during $\beta$-adrenergic stimulation ${ }^{28}$ and during exercise. ${ }^{29}$ It is possible that an increased triglyceride-derived fatty acid oxidation in abdominally obese and obese type 2 diabetic subjects during exercise is driven by the mass of the muscle triglyceride stores, which have been reported to be increased in obese or type 2 diabetic subjects. ${ }^{30-32}$ Finally, in post-obese women, it has been shown that fat oxidation during exercise (at $60-65 \%$ of $\mathrm{VO}_{2}$ max) is subnormal for their high circulating levels of free fatty acids. ${ }^{33,34}$

Overall, on the basis of the above evidence it can be concluded that an impaired capacity to use fat as a fuel may be an important factor in the aetiology of obesity leading to the development and/or maintenance of increased fat stores and leading to weight regain after weight reduction.

Several mechanisms may be responsible for this impaired capacity to utilize fatty acids. First, the availability of fatty acids may be a determining factor for muscle fat oxidation because the blood muscle FFA concentration gradient may be one of the determining factors for muscle FFA uptake. ${ }^{35}$ Second, skeletal muscle characteristics such as fatty acid transport capacity, potential for $\beta$-oxidation, oxidative capacity, fibre 
type pattern, degree of capillarization and tissue blood flow, may be directed more towards fat storage than fat oxidation in obese individuals. ${ }^{36}$ Third, muscle glycolytic flux may affect fatty acid oxidation. Several studies have shown that an increased intracellular availability of glucose during exercise, either by glucose infusion ${ }^{37}$ or by increasing exercise intensity ${ }^{38}$, decreases fatty acid oxidation. Finally, several hormonal and neural factors have been implicated in the disturbed capacity to utilize fat in obesity. In this respect there are strong indications that a lowered sympathetically mediated fat utilization may be of importance in the aetiology of obesity. ${ }^{12,20}$ Thus, several mechanisms have been proposed for the impaired capacity to utilize fat; one or a combination of the above indicated factors may be involved.

\section{ADIPOSE TISSUE LIPOLYSIS}

Several studies have shown a blunted adipose tissue lipolytic response during catecholamine stimulation in obese subjects. Studies in our laboratory have shown a blunted increase in circulating arterial concentrations of glycerol and FFA in obese men during infusion of the non-selective $\beta$-agonist isoprenaline. ${ }^{12,20}$ Subsequent studies showed that this blunted lipolytic response could be ascribed to a diminished function of the $\beta_{2}$-adrenoceptor. ${ }^{39}$ Also, there are indications from in vitro 'adipose tissue' biopsy studies that the decreased $\beta_{2}$-adrenergically mediated lipolytic response may be related to a decreased number of $\beta_{2}$-adrenoceptors. ${ }^{40}$ Additionally, in vitro studies in adipocytes from first-degree relatives of obese subjects ${ }^{4 I}$ and studies in adipocytes from elderly male subjects with several manifestations of the metabolic syndrome also indicate postreceptor alterations at the level of the protein kinase $A /$ hormone sensitive lipase complex. ${ }^{40}$

The molecular mechanisms underlying the activation of lipolysis are not known in detail. Stimulation of adipocytes with catecholamines triggers the translocation of hormone-sensitive lipase from the cytoplasmic compartment to the surface of lipid droplets, and in intact cells this translocation takes place only after phosphorylation of HSL. ${ }^{42} \mathrm{~A}$ complementary mechanism precluding HSL binding to the lipid droplet in intact cells seems to rely on perilipins, a family of closely related proteins located on the surface of lipid droplets in adipocytes. Under basal conditions unphosphorylated perilipin resides upon the lipid droplet. On stimulation of the adipocytes, perilipin phosphorylation would relieve this restraint and allow phosphorylated HSL free access to the lipid droplet. ${ }^{42,43}$ Interestingly, it was shown that a blunted lipolytic response in older rats may be related to a blunted HSL translocation from the cytosol to the lipid droplet and a movement of perilipin away from the lipid droplet. ${ }^{43}$ On the basis of these findings it seems a plausible option that defects in HSL translocation or perilipin function may also play a role in the catecholamine resistance of lipolysis in obese subjects.

\section{FATTY ACID DELIVERY TO MUSCLE AND UPTAKE OF FFA BY MUSCLE}

\section{Fatty acid delivery to muscle}

Sources of fatty acids that are delivered to skeletal muscle via the blood are FFA coupled to albumin and FFA from chylomicrons or very-low-density lipoproteins.

The arterial FFA concentration is strongly determined by lipolysis from the adipose tissue stores. The FFA supply to the muscle cell is determined by the arterial FFA 
concentration times the blood flow through skeletal muscle and has been shown to be strongly coupled to the uptake of FFA by muscle during both rest and exercise. ${ }^{35,44}$ In the basal state, obesity is associated with increased concentrations of circulating fatty acids. Indeed, fatty acid turnover, expressed per fat-free mass, is higher in obese and upperbody-obese subjects as compared to lean or lower-body-obese subjects. ${ }^{45-47}$ These findings indicate that a diminished supply ofFFA is not very likely to be responsible for the lowered muscle FFA uptake in visceral obese subjects during post-absorptive conditions.

As indicated above, the increase in arterial FFA concentration may be blunted during catecholamine-stimulated conditions in obese subjects, resulting in lower or equal circulating FFA concentrations in obese as compared to lean subjects. ${ }^{12}$ Additionally, the capacity to increase muscle blood flow during catecholamine stimulation 12 may be blunted in obese subjects, possibly also contributing to a lowered FFA supply to the muscle cell.

\section{Intramuscular FFA concentration}

Besides FFA supply to muscle, intracellular FFA concentration may determine FFA uptake because the blood-tissue FFA concentration gradient is a strong determinant of skeletal muscle fatty acid uptake. ${ }^{35}$ Skeletal muscle interstitial glycerol concentrations have been shown to be increased in obese subjects. ${ }^{48}$ An increased basal lipolysis may flood the muscle with FFA, thereby decreasing the blood-tissue concentration gradient and decreasing FFA uptake. So far, few data are available on the regulation of muscle lipolysis in obese subjects but data from our laboratory indicate that similar defects in the capacity to increase lipolysis during catecholamine stimulation are present in adipose tissue and skeletal muscle (Blaak et al, unpublished observations).

\section{Lipoprotein lipase}

Lipoprotein lipase, attached to the luminal site of endothelial site, hydrolyses the triacylglycerols (TAGs) in very-low-density lipoproteins and chylomicrons, after which the FFA released from this extracellular lipolysis are mainly taken up by muscle. The few data that are available on muscle lipoprotein lipase activity indicated that fasting activity may be similar in obese as compared to lean women, but that after weight loss this activity may decrease. ${ }^{49}$ However, Astrup and co-workers showed that skeletal muscle LPL activity is similar in post-obese women as compared to controls. ${ }^{50}$ Also, studies of Simoneau and coworkers indicate that heparin-releaseable LPL activity is similar in the skeletal muscle of obese and lean subjects. ${ }^{36}$ Thus, most studies indicate that skeletal muscle LPL activity is not a rate limiting factor for muscle fat oxidation in obesity.

\section{Protein-mediated fatty acid uptake}

New evidence from in vitro and whole-animal studies supports the existence of proteinmediated transmembrane transport of FFA, which is likely to co-exist with passive diffusional uptake. Evidence is also emerging for concerted action between the membrane and cytoplasmic fatty acid-binding proteins (FABPs) that allow for efficient regulation of FFA transport and metabolism. ${ }^{51}$ Little is known about the fatty acid transport capacity in obese humans. In a study by Simoneau and co-workers ${ }^{36}$, neither the content of cytoplasmic fatty acid-binding protein (FABPc) nor that of sarcolemmal FABP was diminished in muscle biopsies of obese subjects. However, it was recently shown that the ability to increase muscle cytoplasmic fatty acid transport protein 
(FABPc) could be directly related to weight loss and to changes in fat oxidation following dietary intervention in obese subjects. ${ }^{52}$ With respect to these data, it remains to be determined whether there is a causal relationship between FABPc, weight loss and changes in fat oxidation, or whether FABPc expression is merely an adaptive response to weight reduction. Nevertheless, these findings underscore a physiologically important role for FABPC in the transport and utilization of FFA in human beings.

Thus, in obesity, several processes involved in adipose tissue lipolysis, FFA delivery, uptake and transport may be affected, and it remains to be determined which defects are most important in the disturbed fat oxidation in the post-absorptive state and during catecholamine stimulation.

\section{SKELETAL MUSCLE CHARACTERISTICS}

\section{Muscle fibre type}

Skeletal muscle contains different types of fibre with a range of oxidative capacities. Type I, slow-twitch fibres, have a high oxidative potential and have an excellent capacity for using lipid as a fuel. Type llb fibres are glycolytic fast-twitch fibres with an almost exclusive reliance on glucose and glycogen for fuel. Type lla fibres are intermediate, with an oxidative capacity that often overlaps that of type I fibres. An inverse relationship between percentage body fat and percentage slow-twitch fibres has been found 24,26 , supporting the hypothesis that muscle fibre type is an aetiological factor for obesity. However, these findings are not consistent. ${ }^{53,54}$

Several studies reported a lowered mitochondrial oxidative capacity (as indicated by a lowered content of malate dehydrogenase, citrate synthase, and cytochrome coxidase) in obese subjects ${ }^{36,53}$, also independent of muscle fibre type. ${ }^{53}$ Data on the capacity for $\beta$-oxidation (as indicated by the key enzyme 3-hydroxyacyl-CoA dehydrogenase) are more controversial, both a similar ${ }^{36,55}$ and a lowered muscle content of this marker of muscle fatty acid oxidation having been reported in (post)obese as compared to lean subjects. ${ }^{50}$

Another step that may possibly be rate limiting for long-chain fatty acid oxidation is the transport of fatty acids into the mitochond ria by means of carnitine palmitoyltransferase (CPT-I). In skeletal muscle of obese subjects CPT-I activity has been reported to be lowered..$^{36}$ Also, CP-T activity has been shown to be correlated with post-absorptive FFA uptake across the leg in visceral obese women. "A recent study looking at the 'in vitro' fat oxidation in muscle biopsies of obese and lean subjects indicated that defects at both CPT-I and post-CPT-I (such as mitochondrial content) levels contribute to the reduced reliance on lipid oxidation in human skeletal muscle in obesity. ${ }^{56}$ One mechanism that may explain the lowered CPT-I activity is an increased content of malonyl-CoA in obese subjects. Malonyl-CoA directly inhibits CPT-I activity, thereby reducing long-chain fatty acid oxidation. An increase in malonyl-CoA has been reported in rodent models of obesity/insulin resistance in conjunction with a decrease in lipid oxidation. ${ }^{57}$ At present, it is not certain whether a possible decrement in CPT-I is mediated through malonylCOA or some other mechanism such as a reduced expression of CP-T.

\section{AVAILABILITY OF GLUCOSE}

The above considerations indicate that a subnormal ability of muscle to oxidize fatty acids is an important contributor to the development of obesity. At first glance, this 
seems at odds with the classic studies of Randle and co-workers ${ }^{58}$ which demonstrated that excessive fat oxidation in skeletal muscle interferes with insulin-mediated glucose uptake by muscle cells. Moreover, it has been proposed that the impairment in fat oxidation in muscle results from glucose inhibition of fatty acid utilization - a 'reverse' Randle cycle in which the intracellular availability of glucose regulates the level of fatty acid oxidation. ${ }^{37,59}$ Superimposed upon this regulatory effect of glucose availability may be the mass effect of FFA availability. Indeed, skeletal muscle glucose uptake is higher in obese as compared to lean subjects during post-absorptive conditions ${ }^{21}$ and during $\beta$-adrenergic stimulation ${ }^{12}$ and this does not change as a result of weight loss. ${ }^{20,21}$ Also, Mandarino et al ${ }^{19}$ showed that, at comparable arterial glucose concentration and higher arterial FFA concentration, leg glucose uptake and oxidation were higher in obese as compared to lean subjects. However, these findings do not exclude the possibility that glucose uptake is increased because of an impaired FFA uptake in muscle, especially in view of the fact that biochemical and physiological examinations of skeletal muscle in obese subjects indicate a reduced capacity for fat oxidation and an increased tendency towards triglyceride storage.

\section{EXERCISE TRAINING AND FAT METABOLISM IN OBESITY}

The effect of exercise training on substrate utilization in lean volunteers is well documented. Endurance exercise training is known to increase fat oxidation during submaximal exercise at a fixed work load in lean subjects. ${ }^{15,17,18}$ Cross-sectional studies also report a higher fat oxidation during exercise after an overnight fast ${ }^{44}$ or after glucose ingestion ${ }^{60,61}$ in trained compared to sedentary men. Some studies also found an enhanced resting fat oxidation after endurance training. 62,63 Thus, endurance training appears to have the capacity to increase fat oxidation in lean subjects. Most studies in lean subjects report an increased mitochondrial content and oxidative capacity ${ }^{64,65}$ and non-plasma fatty acid oxidation as a result of exercise training. ${ }^{15,17,66}$ Several 'in vitro' lipolytic studies report an increased adipose tissue lipolysis after catecholamine stimulation as a result of endurance training. ${ }^{16,67}$ However, these data could not be confirmed in an in vivo microdialysis study. ${ }^{68}$ Previous studies showed a decreased or unchanged resting fat oxidation in obese subjects following weight loss with diet and/or exercise training ${ }^{46,69-71}$ Nicklas et al ${ }^{69}$ showed that basal fat oxidation was decreased in a group of obese post-menopausal women after a 6-month dietary intervention, but the addition of an exercise programme prevented this decrease. These authors speculated that the preservation of lean body mass and an attenuated decline of in vitro adipocyte lipolytic responsiveness might have counteracted any decline in fat oxidation. This is consistent with the findings of van Aggel-Leijssen and colleagues ${ }^{70}$ who showed that exercise training in obese men prevented the fall in fasting fat oxidation that results from diet-induced weight loss (Figure 2).

As indicated above, in lean individuals exercise fat oxidation increases with endurance training. In obese individuals the findings are controversial. Kempen et al showed that fat oxidation during exercise at $45 \%$ of $\mathrm{VO}_{2}$ max was increased in obese women after an 8 -week combined diet and exercise training programme compared to diet alone. ${ }^{54}$ However, in this study subjects were still in negative energy balance at the time of the post-intervention measurements so that no distinction can be made between the effects of the exercise/diet programme and the acute effect of a negative energy balance. Furthermore, van Aggel-Leijssen and colleagues ${ }^{71}$ showed that, in obese men, low-intensity training ( $40 \%$ of $\mathrm{VO}_{2}$ max) resulted in an increased total fat oxidation during 

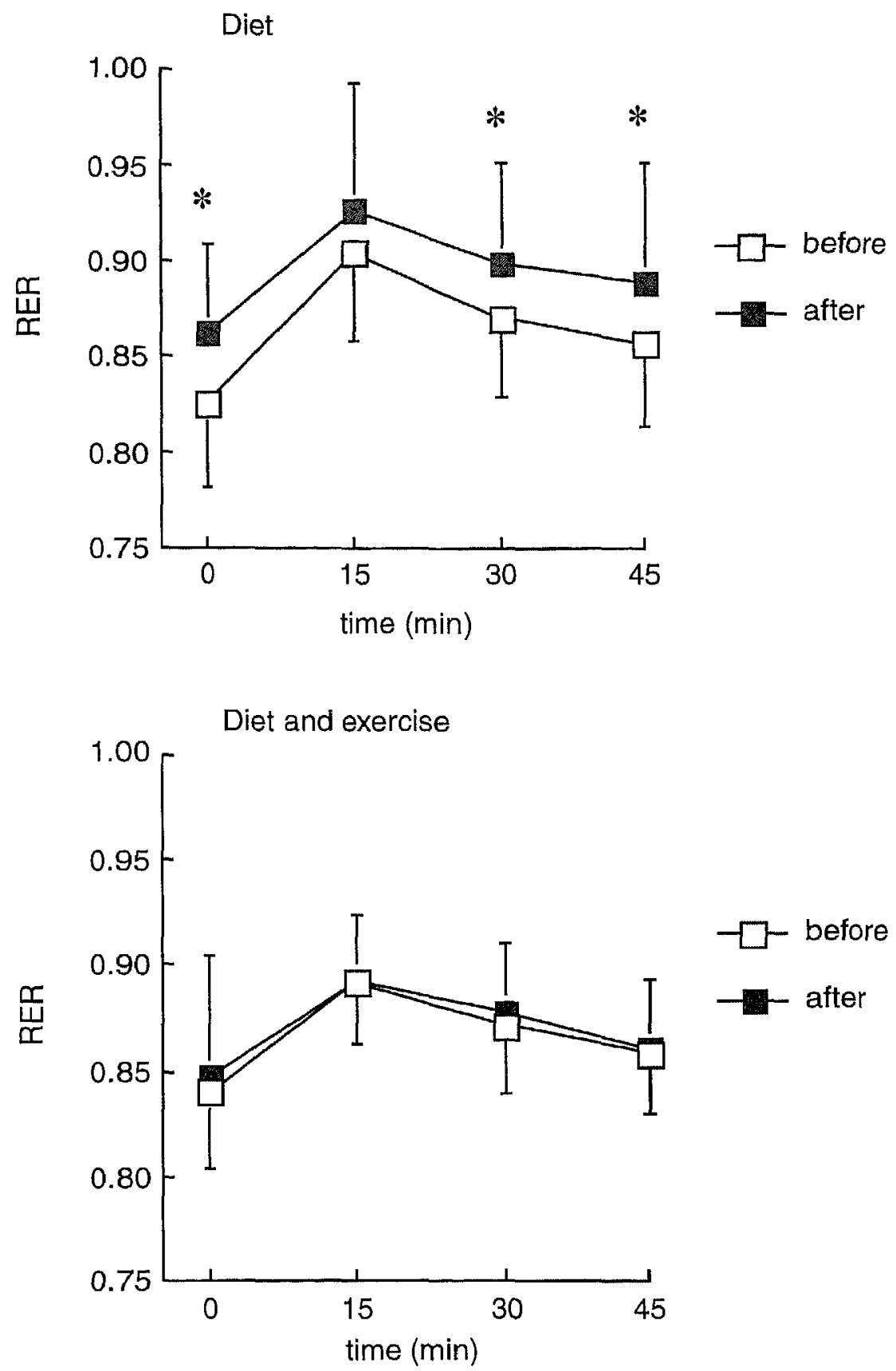

Figure 2. Respiratory exchange ratio (RER) in the diet ( 10 -week energy restriction, VLCD, upper panel) and diet-exercise group (VLCD plus exercise 4 times I hour a week at $40 \% \mathrm{VO}_{2}$ max, lower panel) before and after the intervention $(t=0)$ and during exercise $(t=15-45)$. Subjects $n=17$ obese males in diet group and $n=20$ obese males in diet-exercise group. 
Jerate-intensity exercise, which could be attributed to an increase in non-plasma $r$ acid oxidation, whereas high-intensity training $\left(70 \%\right.$ of $\mathrm{VO}_{2}$ max) did not affect total sxidation. These findings indicate that a low-intensity exercise programme may be e effective in increasing fat oxidation during exercise. Also, relative fat oxidation eased more in upper-body obese women as compared to lower-body obese women, suting the same exercise protocol. ${ }^{72}$ In contrast, Kanaley and colleagues ${ }^{73}$ found that a veek aerobic exercise training programme did not increase exercise fat oxidation in er- and lower-body obese women, but rather did increase exercise carbohydrate Jation. This seems consistent with the data of Pasman and colleagues ${ }^{2}$, showing that a nonth exercise training intervention increased the reliance on carbohydrate lation (increased 24-hour carbohydrate oxidation) in reduced obese men. Also, in a ling study (three times a week, 45-60 minutes of outdoor running and cycling for 3-4 iths) in post-obese women no effect on 24-hour respiratory quotient (RQ) was $\mathrm{Nn} .{ }^{74}$ The underlying explanation for an increased reliance on carbohydrate oxidation be that training resulting in an increased insulin sensitivity may increase glycogen age $^{44}$ and may thereby increase 24-hour carbohydrate storage. Furthermore, these . indicate that exercise training may not be able to increase 24-hour fat oxidation in se subjects, whereas data on exercise fat oxidation are controversial.

hus, to draw more definite conclusions, further well-controlled studies in obese ects have to be performed on exercise training and fat metabolism under different abolic conditions (rest, exercise and post-prandial). In these studies exercise nsity and duration, gender and body fat distribution have to be taken into account.

\section{Practice points}

an thpalied capacity to use fat as a fuel may be an tmportant factor in the aetiology of obesity leading to the dexelopment and for maintenance of fincreased fat stores and leading to weight regaln after weight reduction

if exereise stimulates overall fat oxidation in obese subjects, exercise may be able to compensate for the impaired ablity to exidize fat, thereby promoting a negative fat balance and werght reduction in obese subjects and the naintenance of lat balanke and body weight in reduced obese subjects So tar, the available studles indicate that exercise training may not be able to Inorease 24 hour fat oxidation in obese subjects, whereas data on exereise fat oxidation ane controversibi

\section{Research agends}

further well controlled studles in obese subjedts have to be performed on exerelse training and tat metabolism under different metabolic conditions (rest: extereise and post-prandial), in these studfos exercise intensity and duration. gender and body fat distribution have to be taken into account it is important to have more information on exerise training and 24 theur fat metabolisin in obesity; this is especially releyant because it has been proposed that low-intensity exereise may be more benefical in improving at oxidation. during exereise, but that high-intensity training nay be nore effective in increasing post-exercise fat oxidation 
Also, it is important to have more information on 24-hour fat metabolism; this is especially relevant because it has been proposed that low-intensity exercise may be more beneficial in improving fat oxidation during exercise ${ }^{71}$, but that high-intensity training may be more effective in increasing post-exercise fat oxidation. ${ }^{3}$ Because a disturbed muscle fat oxidation may be a primary event in the aetiology of obesity it is of the utmost importance to know whether, and how, exercise training may compensate for these impairments.

\section{REFERENCES}

I. Saris WHM. Physical activity and body weight regulation. In Bouchard C \& Bray GA (eds) Regulation of Body Weight, pp 135-148. Chichester: John Wiley, 1996.

2. Pasman W], Westerterp MS \& Saris WH. The effect of body weight changes and endurance training on 24h substrate oxidation. International Journal of Obesity and Related Metabolic Disorders 1999; 23: $1223-1232$.

3. Tremblay A, Doucet E \& Imbeault P. Physical activity and weight maintenance. International Journal of Obesity and Related Metabolic Disarders 1999; 23 (supplement 3): S50-554.

4. van Baak MA. Exercise training and substrate utilisation in obesity. International journal of Obesity and Related Metabolic Disorders 1999; 23 (supplement 3): SII-SI7.

5. Stallknecht B, Larsen J], Mikines $\mathrm{KJ}$ et al. Effect of training on insulin sensitivity of glucose uptake and lipolysis in human adipose tissue. American Journal of Physiology, Endocrinalogy and Metabolism 2000; 279: E376-E385.

6. Wood PD, Stefanick ML, Dreon DM et al. Changes in plasma lipids and lipoproteins in overweight men during weight loss through dieting as compared with exercise. New England Journal of Medicine 1988; 319: 1173-1179.

7. Lesniak KT \& Dubbert PM. Exercise and hypertension. Current Opinion in Cardiology 200।; 16: 356-359.

8. Brownell KD. Exercise and obesity treatment: psychological aspects. International journal of Obesity and Related Metabolic Disorders 1995; 19 (supplement 4): S122-S125.

9. Wei M, Gibbons LW, Mitchell TL et al. The association between cardiorespiratory fitness and impaired fasting glucose and type 2 diabetes mellitus in men. Annals of internal Medicine 1999; 130: 89-96.

10. Lee CD, Blair SN \& Jackson AS. Cardiorespiratory fitness, body composition, and all-cause and cardiovascular disease mortality in men. American Journal of Clinical Nutrition 1999; 69: 373-380.

* II. Colberg SR, Simoneau JA, Thaete FL \& Kelley DE. Skeletal muscle utilization of free fatty acids in women with visceral obesity. Journal of Clinical Investigation 1995; 95: 1846-1853.

*12. Blaak EE, van Baak MA, Kemerink G] et al. Beta-adrenergic stimulation of energy expenditure and forearm skeletal muscle metabolism in lean and obese men. American Journal of Physiology 1994; 267: E306-E3I5.

13. Zurlo F, Lillioja S, Esposito-Del Puente A et al. Low ratio of fat to carbohydrate oxidation as predictor of weight gain: study of 24-h RQ. American Journal of Physiology 1990; 259: E650-E657.

14. Froidevaux F, Schutz $Y$, Christin L \& Jequier E. Energy expenditure in obese women before and during weight loss, after refeeding, and in the weight-relapse period. American Journal of Clinical Nutrition 1993; 57: $35-42$.

15. Martin WH 3rd, Dalsky GP, Hurley BF et al. Effect of endurance training on plasma free fatty acid turnover and oxidation during exercise. Americon Journal of Physiology 1993; 265: E708-E7/4.

16. Crampes F, Beauville M, Riviere D \& Garrigues M. Effect of physical training in humans on the response of isolated fat cells to epinephrine. Journal of Applied Physiology 1986; 61: 25-29.

17. Phillips SM, Green HJ, Tarnopolsky MA et al. Effects of training duration on substrate turnover and oxidation during exercise. Journal of Applied Physiology 1996; 81: 2182-2191.

18. Sial S, Coggan AR, Hickner RC \& Klein S. Training-induced alterations in fat and carbohydrate metabolism during exercise in elderly subjects. American Journal of Physiology 1998; 274: E785-E790.

19. Mandarino LJ, Consoll A, Jain A \& Kelley DE. Interaction of carbohydrate and fat fuels in human skeletal muscle: impact of obesity and NIDDM. American Journal of Physiology 1996; 270: E463-E470.

20. Blaak EE, van Baak MA, Kemerink G] et al. beta-Adrenergic stimulation of skeletal muscle metabolism in relation to weight reduction in obese men. American Journal of Physiology 1994; 267: E316-E322.

*21. Keiley DE, Goodpaster B, Wing RR \& Simoneau JA. Skeletal muscle fatty acid metabolism in association with insulin resistance, obesity, and weight loss. American Journal of Physiology 1999; 277: El I30-El I4I. 
22. Astrup A, Buemann B, Christensen NJ \& Toubro S. Failure to increase lipid oxidation in response to increasing dietary fat content in formerly obese women. American Journal of Physiology 1994; 266: E592-E599,

23. Raben $A$, Andersen $H B$, Christensen $N$ J et al. Evidence for an abnormal postprandial response to a high-fat meal in women predisposed to obesity. American Journal of Physiology 1994; 267: E549-E559.

24. Wade AJ, Marbut MM \& Round JM. Muscle fibre type and aetiology of obesity. Lancet 1990; 335: 805-808.

25. Geerling BJ, Alles MS, Murgatroyd PR et al. Fatness in relation to substrate oxidation during exercise. International Journal of Obesity and Related Metabolic Disorders 1994; 18: 453-459.

26. Helge JW, Fraser AM, Kriketos $A D$ et al. Interrelationships between muscle fibre type, substrate oxidation and body fat. International Journal of Obesity and Related Metabolic Disorders 1999; 23: 986-991.

*27. Horowitz JF \& Klein S. Oxidation of nonplasma fatty acids during exercise is increased in women with abdominal obesity. Journal of Applied Physiology 2000; 89: 2276-2282.

28. Blaak EE, Wagenmakers A], Glatz JF et al. Plasma FFA utilization and fatty acid-binding protein content are diminished in type 2 diabetic muscle. American Journal of Physiology, Endocrinology and Metabolism 2000; 279: El46-EI54.

*29. Blaak EE, van Aggel-Leijssen DP, Wagenmakers AJ et al. Impaired oxidation of plasma-derived fatty acids in type 2 diabetic subjects during moderate-intensity exercise. Diabetes 2000; 49: 2102-2107.

30. Malenfant $P$, Joanisse DR, Theriault $R$ et al. Fat content in individual muscle fibers of lean and obese subjects. International Journal of Obesity and Related Metabolic Disorders 2001; 25: 1316-1321.

31. Malenfant $P$, Tremblay $A$, Doucet $E$ et al. Elevated intramyocellular lipid concentration in obese subjects is not reduced after diet and exercise training. Americon Journal of Physiology, Endocrinology and Metabolism 200I; 280: E632-E639.

32. Levin K, Daa Schroeder H, Alford FP \& Beck-Nielsen H. Morphometric documentation of abnormal intramyocellular fat storage and reduced glycogen in obese patients with Type II diabetes. Diabetologia 2001; 44: 824-833.

33. Ranneries C, Bulow J, Buemann B et al. Fat metabolism in formerly obese women. Americon journol of Physiology 1998; 274: EI55-El61.

34. Ezell DM, Geiselman PJ, Anderson AM et al. Substrate oxidation and availability during acute exercise in non-obese, obese, and post-obese sedentary females. Internotional journal of Obesity and Related Metabolic Disorders 1999; 23: 1047-1056.

35. van der Vusse GJ \& Reneman RS. Lipid metabolism in muscle. In Handbook of Physialogy. Exercise: Regulation and Integration of Mutiple Systems, PP 952-994. Bethesda MD: American Physiology Society 1996.

36. Simoneau JA, Veerkamp JH, Turcotte LP \& Kelley DE. Markers of capacity to utilize fatty acids in human skeletal muscle: relation to insulin resistance and obesity and effects of weight loss. Faseb journal 1999; 13: $2051-2060$.

37. Sidossis LS \& Wolfe RR. Glucose and insulin-induced inhibition of fatty acid oxidation: the glucose-facty acid cycle reversed. American journal of Physiology 1996; 270: E733-E738.

38. Coyle EF, Jeukendrup AE, Wagenmakers AJ \& Saris WH. Fatty acid oxidation is directly regulated by carbohydrate metabolism during exercise. American journal of Physiology 1997; 273: E268-E275.

39. Schiffelers SL, Saris WH, Boomsma F \& van Baak MA. beta(I)- and beta(2)-Adrenoceptor-mediated thermogenesis and lipid utilization in obese and lean men. Journal of Clinicol Endocrinology and Metabolism 2001; 86: 2191-2199.

40. Reynisdottir S. Eriksson M, Angelin B \& Arner P. Impaired activation of adipocyte lipolysis in familial combined hyperlipidemia. Journal of Clinical Investigation 1995; 95: 2161-2169.

41. Hellstrom L, Langin D, Reynisdottir $S$ et al. Adipocyte lipolysis in normal weight subjects with obesity among first-degree relatives. Diabetologia 1996; 39: 921-928.

42. Holm C, Osterlund T, Laurell H \& Contreras JA. Molecular mechanisms regulating hormone-sensitive lipase and lipolysis. Annual Review of Nutrition 2000; 20: 365-393.

43. Clifford GM, Londos C, Kraemer FB et al. Translocation of hormone-sensitive lipase and perilipin upon lipolytic stimulation of rat adipocytes. Journal of Biological Chemistry 2000; 275: $5011-5015$.

44. Turcotte LP, Richter EA \& Kiens B. Increased plasma FFA uptake and oxidation during prolonged exercise in trained vs. untrained humans. American Journal of Physiology 1992; 262: E791-E799.

45. Wolfe RR, Peters EJ, Klein $S$ et al. Effect of short-term fasting on lipolytic responsiveness in normal and obese human subjects. Americon Journal of Physiology 1987; 252: El 89-El96.

46. Kanaley JA, Cryer PE \& Jensen MD. Fatty acid kinetic responses to exercise. Effects of obesity, body fat distribution, and energy-restricted diet. Journal of Clinical Investigation 1993; 92: 255-261.

47. Jensen MD, Haymond MW, Rizza RA et al. Influence of body fat distribution on free fatty acid metabolism in obesity. Journal of Clinical Investigation 1989; 83: 1168-1173.

48. Bolinder ], Kerckhoffs DA, Moberg E et al. Rates of skeletal muscle and adipose tissue glycerol release in nonobese and obese subjects. Diabetes 2000; 49: 797-802. 
49. Eckel RH, Yost T] \& Jensen DR. Sustained weight reduction in moderately obese women results in decreased activity of skeletal muscle lipoprotein lipase. Europeon journol of Clinical Investigation 1995; 25; $396-402$.

50. Astrup A, Buemann B, Toubro $S$ \& Raben A. Defects in substrate oxidation involved in the predisposition to obesity. Proceedings of Nutrition Society 1996; 55: 817-828.

51. Glatz JF \& Storch J. Unravelling the significance of cellular fatty acid-binding proteins. Current Opinion in Lipidology 2001; 12: 267-274.

52. Blaak EE, Glatz JF \& Saris WH. Increase in skeletal muscle fatty acid binding protein (FABPC) content is directly related to weight loss and to changes in fat oxidation following a very low calorie diet. Diabetologia 2001; 44: 2013-2017.

53. Simoneau JA \& Bouchard C. Skeletal muscle metabolism and body fat content in men and women. Obesity Research 1995; 3: 23-29.

54. Kempen KP, Saris WH \& Westerterp KR. Energy balance during an 8-wk energy-restricted diet with and without exercise in obese women. American Journal of Clinical Nutrition 1995; 62: 722-729.

55. Kempen KP, Saris WH, Kuipers $\mathrm{H}$ et al. Skeletal muscle metabolic characteristics before and after energy restriction in human obesity: fibre type, enzymatic beta-oxidative capacity and fatty acid-binding protein content. Europeon Journal of Clinical investigation 1998; 28: 1030-1037.

56. Kim JY, Hickner RC, Cortright RL et al. Lipid oxidation is reduced in obese human skeletal muscle. American Journal of Physiology, Endocrinology and Metabolism 2000; 279: El039-El044.

57. Saha AK, Vavvas D, Kurowski TG et al. Malonyl-CoA regulation in skeletal muscle: its link to cell citrate and the glucose-fatty acid cycle. American Journal of Physiology 1997; 272: E64I-E648.

58. Randle PJ. Regulatory interactions between lipids and carbohydrates: the glucose fatty acid cycle after 35 years. Diabetes Metabolism Reviews 1998; 14: 263-283.

59. Wolfe RR. Metabolic interactions between glucose and fatty acids in humans. American journal of Clinical Nutrition 1998; 67(supplement 3): 5195-526S.

60. van Loon LJ, Jeukendrup AE, Saris WH \& Wagenmakers AJ. Effect of training status on fuel selection during submaximal exercise with glucose ingestion. Journal of Applied Physiology 1999; 87: 1413-1420.

61. Jeukendrup AE, Mensink M, Saris WH \& Wagenmakers AJ. Exogenous glucose oxidation during exercise in endurance-trained and untrained subjects. Journal of Applied Physiology 1997; 82: 835-840.

62. Romijn JA, Klein S, Coyle EF et al. Strenuous endurance training increases lipolysis and triglyceride-fatty acid cycling at rest. Journal of Applied Physiology 1993; 75: 108-113.

63. Poehlman ET, Gardner AW, Arciero P] et al. Effects of endurance training on total fat oxidation in elderly persons. Journal of Applied Physiology 1994; 76: 2281-2287.

64. Brouns F \& van der Vusse G]. Utilization of lipids during exercise in human subjects: metabolic and dietary constraints. British Journal of Nutrition 1998; 79: 117-128.

65. Simoneau JA. Adaptation of human skeletal muscle to exercise-training. International journol of Obesity and Related Metobolic Disorders 1995; 19 (supplement 4): \$9-SI3.

66. Hurley BF, Nemeth PM, Martin WH 3rd et al. Muscle triglyceride utilization during exercise: effect of training. Journol of Applied Physiology 1986; 60: 562-567.

67. Despres JP, Bouchard C, Sayard R et al. Effects of exercise-training and detraining on fat cell lipolysis in men and women. European Journal of Applied Physiology and Occupational Physiology 1984; 53: 25-30.

68. Stallknecht B, Simonsen $L$, Bulow J et al. Effect of training on epinephrine-stimulated lipolysis determined by microdialysis in human adipose tissue. Americon Journol of Physiology 1995; 269: E1059-E1066.

69. Nicklas B], Rogus EM \& Goldberg AP. Exercise blunts declines in lipolysis and fat oxidation after dietaryinduced weight loss in obese older women. American Journal of Physiology 1997; 273: El49-EI55.

*70. van Aggel-Leijssen DP, Saris WH, Hul GB \& van Baak MA. Short-term effects of weight loss with or without low-intensity exercise training on fat metabolism in obese men. American journal of Clinical Nutrition 2001; 73: 523-531.

*7I. van Aggel-Leijssen DP, Saris WH, Wagenmakers AJ et al. Effect of exercise training at different intensities on fat metabolism of obese men. Journal of Applied Physiology 2002; 92: 1300-1309.

*72. van Aggel-Leijssen DP, Saris WH, Wagenmakers AJ et al. The effect of low-intensity exercise training on fat metabolism of obese women. Obesity Research 2001; 9: 86-96.

*73. Kanaley JA, Weatherup-Dentes MM, Alvarado CR \& Whitehead G. Substrate oxidation during acute exercise and with exercise training in lean and obese women. Europeon journol of Applied Physiology 2001; 85: 68-73.

*74. Buemann B, Astrup A \& Christensen NJ. Three months aerobic training fails to affect 24-hour energy expenditure in weight-stable, post-obese women. International journal of Obesity and Related Metabolic Disorders 1992; 16: 809-816. 